\title{
Substitution Effect of Enzymatically Hydrolyzed Purple Sweet Potato Powder on Skim Milk in Yogurt Preparation
}

\author{
Dong Chung Kim · Sun Im Won • Man-Jin In*
}

\section{요구르트 제조에서 자색 고구마 효소 분해물의 탈지분유 대체 효과}

김동청 · 원선임 · 인만진*

Received: 30 July 2015 / Accepted: 25 August 2015 / Published Online: 31 December 2015

(C) The Korean Society for Applied Biological Chemistry 2015

\begin{abstract}
Yogurt was prepared with different substitution ratio [10, 30, and 50\% (w/w)] of skim milk with enzymatically hydrolyzed purple sweet potato powder (EHPSPP) and fermented at $40^{\circ} \mathrm{C}$ for $15 \mathrm{~h}$. Fermentation characteristics and antioxidant activities of the yogurt were evaluated in terms of acid production ( $\mathrm{pH}$ and titratable acidity) and lactic acid bacterial counts and DPPH radical scavenging activity, respectively. After $15 \mathrm{~h}$ fermentation, titratable acidity of EHPSPP yogurt was $0.80-0.89 \%$ and was lower than that $(0.93 \%)$ of yogurt made without EHPSPP. The acid production and the number of viable lactic acid bacterial cell decreased with increasing the substitution ratio. The sensory score of EHPSPP yogurt prepared with $30 \%$ substitution ratio showed the highest values in taste and overall acceptability among the tested yogurt preparations. DPPH radical scavenging activity increased with increasing the substitution ratio in yogurt fermented for $12 \mathrm{~h}$. The total phenolic content of 30\% EHPSPP yogurt was $40 \%$ higher than that of skim milk yogurt. These results suggest that EHPSPP can be used as substituent of skim milk and the optimum substitution ratio is around $30 \%$.
\end{abstract}

\section{C. Kim}

Department of Integrated Materials Engineering, Chungwoon University, Incheon 402-803, Republic of Korea

S. I. Won · M.-J. In

Department of Human Nutrition and Food Science, Chungwoon University, Hongseong 350-701, Republic of Korea

*Corresponding author (M.-J. In: manjin@chungwoon.ac.kr)

This is an Open Access article distributed under the terms of the Creative Commons Attribution Non-Commercial License (http://creativecommons. org/licenses/by-nc/3.0/) which permits unrestricted non-commercial use, distribution, and reproduction in any medium, provided the original work is properly cited.
Keywords antioxidant activity $\cdot$ enzymatically hydrolyzed purple sweet potato $\cdot$ fermentation characteristics $\cdot$ yogurt

\section{서 론}

우유 또는 탈지유에 젖산균 또는 효모로 발효시켜 산미와 향미 를 강화시킨 요구르트는 주원료인 우유 성분 이외에 젖산균의 작용에 의한 젖산, peptone, peptide, 미량의 생리활성물질과 젖 산 균체가 포함되어 있는 우수한 식품이다(Gilliland, 1989). 또 한 요구르트는 우유보다 영양과 소화율이 향상된 유가공 제품 으로 독특한 풍미와 젖산균의 장내증식에 의한 정장작용 등과 같은 건강 증진 효과로 인하여 세계적으로 수요가 꾸준히 증가 하고 있다. 우리나라에서도 액상 요구르트가 주종을 이루었으나 경제발달과 함께 건강에 대한 관심의 증대로 기존의 액상 요구 르트보다 유고형분 함량과 젓산균수가 많은 커드상의 호상 요 구르트가 판매되기 시작하면서 호상 제품의 소비량이 꾸준히 증 가하고 있다. 최근에는 다양한 생리활성 성분을 함유하고 있는 천연의 부재료[매실(Lee 등, 2002), 인삼(Lee와 Paek, 2003), 클 로렐라(Sung 등, 2005), 마늘(Cho 등, 2007), chitooligosaccharides (Lee와 Kang, 2010), 오디분말(Sung과 Choi, 2014), 통보리가루 (Lee 등, 2015a), 등]를 요구르트에 첨가하여 기존 요구르트의 기능성에 새로운 생리활성을 강화시킨 요구르트를 제조하려는 결과가 보고되고 있다.

한편, 고구마(Ipomoea batatas L.)는 수분이 $70 \%$ 이며 고형분 중 $75 \%$ 이상이 탄수화물로 구성되어 식량작물로 중요할 뿐만 아니라, 식이섬유, 무기질과 비타민 등을 다량 함유하고 있어 영양학적으로도 우수한 식품이다(Ravindran 등, 1995). 고구마 에는 $\beta$-카로틴, 안토시아닌, 폴리페놀, 강글리오사이드 등과 같 은 기능성 성분의 존재가 보고되어 있으며(Almeida와 Penteado, 1988; Lee 등, 2007), 특히 표피와 육질이 진한 자색을 띠는 자 
색고구마는 높은 안토시아닌 함량에 기인하는 항돌연변이, 항산 화, 간기능 보호 등의 기능이 있는 것으로 보고되어 있다(Choi 등, 2003; Park 등, 2011a; Kim 등, 2015). 따라서 최근에는 자색고구마를 식품소재로 첨가하여 제품의 물성과 품질을 개선 함과 동시에 자색고구마의 생리활성을 활용하는 연구가 머핀 (Ko와 Seo, 2010), 동치미 냉면 육수(Seo 등, 2011), 막걸리 (Cho 등, 2012), 쿠키(Liu 등, 2013), 청국장(Lee, 등, 2014), 소시지(Lee 등, 2015b) 등에서 꾸준하게 수행되었으며 가공식품 의 원료로 자색고구마는 지속적으로 활용되고 있는 추세이다. 자색고구마를 이용한 요구르트 제조에는 증자한 고구마를 puree 형태로, 혹은 동결건조한 생고구마를 분말로 우유와 탈지분유에 첨가하는 선행연구(Jung과 Ju, 1997; Lee 등, 1999; Chun 등, 2000)가 있다. 그러나 요구르트 제조에 사용되는 젖산균의 낮은 전분 분해효소 활성으로 자색고구마에 함유된 전분은 요구르트 제조에 효율적으로 이용되지 못하며 자색고구마의 첨가는 주로 안토시아닌 색소에 의한 요구르트의 관능적 특성과 생리활성 향 상에 기여하는 것으로 판단된다.

따라서 본 연구에서는 항산화 활성이 우수한 자색고구마를 식품소재로 활용하는 연구의 일환으로 요구르트 발효에 대한 자 색고구마 분말의 영향을 조사하였다. 특히 요구르트 원료로 사 용되는 탈지분유의 일부를 효소로 당화시킨 자색고구마 분말로 대체하여 요구르트 발효특성과 관능적 특성, 항산화 활성을 조 사함으로써 자색고구마가 요구르트 발효에 이용될 수 있는 최 적의 첨가량을 찾고자 하였다.

\section{재료 및 방법}

재료. 탈지분유는 서울우유협동조합의 제품이었고, 자색고구마 는 2013년산 신자미 품종으로 재배농가(보령, 충남)로부터 구입 하여 기존의 방법 $(\mathrm{Kim}$ 등, 2014)에 준하여 열풍건조로 분말화 한 후 $-20^{\circ} \mathrm{C}$ 에 보관하며 이용하였다. 요구르트 제조의 starter는 Rhone-Poulenc사(USA)의 혼합유산균제제 ABT-B Yogurt Culture 를 별도의 배양 없이 사용하였다.

자색고구마 효소분해물의 제조 및 요구르트 배양. 현미 당화물 의 제조방법(In 등, 2009)과 동일하게 입도 200-300 $\mu \mathrm{m}$ 의 자색 고구마 분말 $20 \%$ 현탁액에 $\alpha$-amylase와 glucoamylase (Sigma Chem., USA)를 처리하여 당화시킨 후 동결건조하여 자색고구 마 효소분해물을 제조하였다. 자색고구마 효소분해물을 함유한 요구르트는 탈지분유 $10 \%$ 현탁액을 기준으로 탈지분유 사용량 의 $10-50 \%$ 를 자색고구마 효소분해물로 대체하여 잘 균질화하 고 $100^{\circ} \mathrm{C}$ 에서 10 분간 열처리한 후 starter를 $0.02 \%$ 접종하여 $40^{\circ} \mathrm{C}$ 항온기에서 정치배양하여 제조하였다.

$\mathbf{p H}$ 와 적정산도. 요구르트의 $\mathrm{pH}$ 는 $\mathrm{pH}$ meter (model 915DC, Istek, Korea)를 이용하여 측정하였고, 적정산도는 요구르트를 멸 균 식염수로 10 배 희석한 후 phenolphthalein을 지시약으로 $0.01 \mathrm{~N} \mathrm{NaOH}$ 로 적정하여 젖산으로 환산하였다.

환원당. 요구르트를 적당히 희석한 후 DNS (3,5-dinitrosalicylic acid)법을 사용하여 분석하였다. 포도당으로 작성된 표준곡선을 이용하여 환원당의 함량을 계산하였다.

젖산균수. 무균적으로 채취한 요구르트 $1 \mathrm{~g}$ 을 멸균 생리식염수 로 단계적으로 희석한 후 젖산균 배양용 배지(Lactobacillus MRS agar, Difco Laboratories, Detroit, MI, USA)에 $1 \mathrm{~mL}$ 씩 pour plate method로 접종하고 $30^{\circ} \mathrm{C}$ 에서 $36-48$ 시간 배양하여
형성된 colony를 계측하여 시료 $\mathrm{g}$ 당 colony forming units $(\mathrm{CFU} / \mathrm{g})$ 로 나타내었다.

색도. 요구르트의 색은 분광측색계 JS555 (Color Techno System Corp., Japan)를 이용하여 L값(명도), a값(적색도), b값(황색도)을 10 회 측정하여 평균값으로 얻었으며, 이때 표준 백색판의 $\mathrm{L}, \mathrm{a}$, $\mathrm{b}$ 값은 각각 $98.37,-0.04,-0.38$ 이었다.

총 폴리페놀 함량 및 DPPH 라디칼 소거활성. 요구르트의 총 폴리페놀 화합물 함량은 Folin-Ciocalteu 방법(Folin과 Denis, $1912)$ 으로 측정하였다. 원심분리 $\left(1,000 \times \mathrm{g}, 15\right.$ 분, $\left.4^{\circ} \mathrm{C}\right)$ 하여 얻은 요구르트 상등액 $0.5 \mathrm{~mL}$ 에 $25 \% \quad \mathrm{Na}_{2} \mathrm{CO}_{3}$ 용액 $0.5 \mathrm{~mL}$ 를 가하 고 상온에서 3 분간 방치 후 $2 \mathrm{~N}$ Folin-Ciocalteu 시약 $0.25 \mathrm{~mL}$ 를 첨가하여 상온에서 1시간 반응시킨 다음 $750 \mathrm{~nm}$ 에서 흡광 도를 측정하였다. Chlorogenic acid를 표준물질로 작성한 표준 곡선으로 총 폴리페놀 함량을 계산하였다. 요구르트의 항산화 활성은 DPPH (2,2-diphenyl-1-picryl-hydrazyl) radical의 소거활 성(Blois, 1958)으로 비교하였다. 원심분리로 얻은 요구르트 상 등액 $1 \mathrm{~mL}$ 에 $0.15 \mathrm{mM} \mathrm{DPPH}$ 용액 $3 \mathrm{~mL}$ 를 가한 후 상온에서 30 분간 반응시킨 다음 $525 \mathrm{~nm}$ 에서 흡광도를 측정하였다. 시료 첨가구와 증류수 첨가구의 흡광도 차이를 백분율 $(\%)$ 로 나타내 었다.

관능검사. 관능검사는 12 시간 발효시킨 요구르트에 $10 \%$ 로 설 탕을 가하고 $4^{\circ} \mathrm{C}$ 에서 24 시간 보관 후 청운대학교 식품영양학과 대학생 10 명을 대상으로 색상, 맛, 향, 종합적인 기호도에 대하 여 최저 1점, 최고 5 점의 5 단계 평가법으로 평가하였다.

통계분석. 관능적 특성 결과는 SPSS (Statistical Package for Social Science, SPSS Inc., USA, version 11.5)로 통계처리 하 였으며 ANOVA를 이용하여 Duncan's multiple range test로 $5 \%$ 수준에서 각 시료간의 유의성을 검증하였다 $(p<0.05)$.

\section{결과 및 고찰}

자색고구마 효소분해물. 일반적으로 요구르트 발효에 사용되는 젖산균은 전분 당화효소의 활성이 미약하므로 요구르트 제조에 서 탈지분유를 자색고구마 분말로 대체하기 위하여는 액화 및 당화효소를 사용하여 자색고구마에 함유된 전분을 당화시키는 것이 필요하다. 당화 후 동결건조한 자색고구마 당화물의 환원 당 함량은 $46.6 \%$ 로 당화하지 않은 자색고구마 분말의 $2.1 \%$ 에 비하여 크게 향상되었다. 자색고구마(품종: 신자미) 분말의 전분 함량이 59.31\%인 보고(Park 등, 2011b)를 고려하면 전분의 $75 \%$ 이상이 환원력을 나타내는 저분자 당류로 분해된 것으로 사료 된다.

$\mathbf{p H}$ 와 적정산도의 변화. 요구르트 제조 원료인 $10 \%(\mathrm{w} / \mathrm{w})$ 탈지 분유를 기준으로 자색고구마 효소분해물로 탈지분유 사용량의 0 (대조군), $10,30,50 \%$ 를 대체하여 원료를 준비하고 $40^{\circ} \mathrm{C}$ 에서 15 시간 동안 발효시켜 요구르트를 제조하여 $\mathrm{pH}$ 와 적정산도의 변화를 경시적으로 측정하였다. 요구르트의 $\mathrm{pH}$ 는 모든 실험구 에서 발효 9시간까지 급격하게 감소하였으며, 그 이후 발효 15 시간까지 다소 완만하게 감소하였다(Fig. 1A). 발효 초기(3시간) 에서 자색고구마 효소분해물 첨가군의 $\mathrm{pH}$ 가 대조군보다 낮았 으며, 이는 자색고구마 분해물에 함유된 발효성 저분자 당류에 의한 것으로 사료되었다. 그러나 발효 후기(15시간)에서는 모든 실험군의 $\mathrm{pH}$ 는 3.9 부근으로 유사하였으며, 증자한 자색고구마 puree를 첨가하여 제조한 요구르트에서 발효 24시간에 $\mathrm{pH}$ 가 

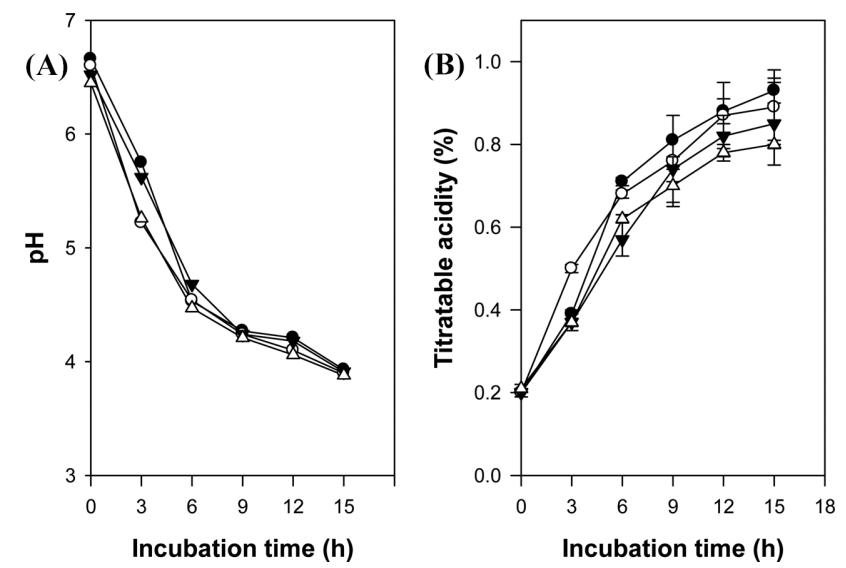

Fig. 1 Change in pH (panel A) and titratable acidity (panel B) of yogurt prepared with different substitution ratios of skim milk with enzymatically hydrolyzed purple sweet potato powder during fermentation at $40^{\circ} \mathrm{C}$ for 15 h. Symbols: $0 \%$ (control); $\bigcirc, 10 \% ; \nabla, 30 \%$; $\nabla, 50 \%$.

3.97-4.04 범위의 값을 보인 결과(Chun 등, 2000)보다 낮은 $\mathrm{pH}$ 를 보였다. 요구르트 발효 중 적정산도의 변화는 $\mathrm{pH}$ 의 변화와 유사하여, 모든 실험구에서 발효 9시간까지 급격하게 증가하였 다(Fig. 2B). 발효 9시간 이후 대조군의 $\mathrm{pH}$ 가 자색고구마 분해 물 첨가군 보다 높음에도 적정산도가 더 높게 나타난 것은 탈 지분유에 함유된 인산염, 유단백질 등의 $\mathrm{pH}$ 완충작용(Walstra와 Jenness, 1984)에 기인하는 것으로 판단된다. 발효 15시간 후 대 조구의 산도는 $0.93 \%$, 자색고구마 분해물 첨가 요구르트는 각 각 $0.89,0.85,0.80 \%$ 로 자색고구마 분해물의 사용량이 증가할 수록 산의 생성은 감소하였다. 이러한 결과가 대부분의 식품소 재를 첨가하여 제조한 요구르트의 품질특성에서 적정산도는 첨 가량에 비례하여 증가하는 추세를 보인다는 보고(Sung 등, 2005; Sung과 Choi, 2014)와 상이한 것은 본 연구는 탈지분유 에 자색고구마 분해물의 추가로 첨가한 것이 아니라 탈지분유 의 사용량을 $10 \sim 50 \%$ 줄이고 자색고구마 분해물로 대체한 요구 르트 발효기질을 사용하였기 때문이다. 따라서 본 연구의 적정 산도 $(0.80-0.89 \%)$ 가 증자한 자색고구마 puree를 첨가한 요구르 트(Chun 등, 2000)의 적정산도(1.1-1.3\%)보다 낮은 것도 사용 균주의 차이뿐만 아니라 발효기질 조성의 차이에 기인하는 것 으로 판단된다.

환원당과 젓산균 수의 변화. 자색고구마 효소분해물로 탈지분유 를 대체하여 제조한 요구르트의 환원당 변화는 Fig. $2 \mathrm{~A}$ 와 같다. 발효 전 실험군의 환원당 함량은 대조군 $4.58 \%$, 실험군 4.70 $4.77 \%$ 로 유사하였으며, 발효가 진행됨에 따라 급격하게 감소하 였다. 발효 9시간에 환원당 함량은 대조군 $3.46 \%$, 탈지분유 10 , 30 및 $50 \%$ 대체 요구르트는 각각 $3.72,4.27,4.40 \%$ 로, 탈지분 유 대체 정도가 높아질수록 발효과정에서 환원당의 감소 정도 가 낮아지는 경향이었다. 발효과정에서 환원당이 젖산균 등의 미생물에 의하여 영양원으로 이용되고 동시에 유기산, 알코올, 이산화탄소 등의 물질로 변환되므로 환원당이 감소하는데, 자색 고구마 효소분해물에 의한 탈지분유 대체 정도가 증가할수록 환 원당 소비가 감소하므로 젖산균 생균수를 조사하였다(Fig. 2B). 젓산균 생균수는 모든 실험구에서 3 시간까지 급격한 증가를 나 타냈으며, 그 이후 15 시간까지 대조구는 매우 완만하게 증가하 였으나 탈지분유 대체구에서는 큰 변화가 없었다. 발효 12 시간
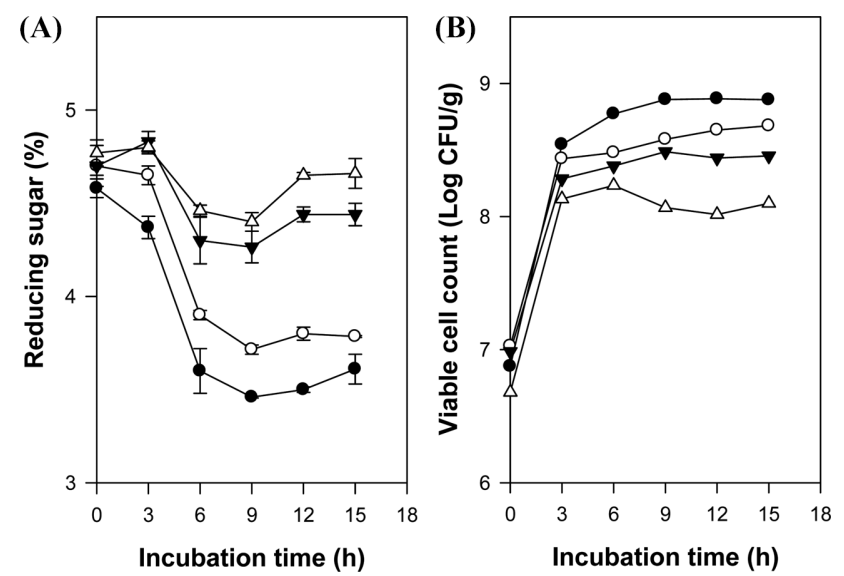

Fig. 2 Change in reducing sugar contents (panel A) and lactic acid bacteria counts (panel B) of yogurt prepared with different substitution ratios of skim milk with enzymatically hydrolyzed purple sweet potato powder during fermentation at $40^{\circ} \mathrm{C}$ for $15 \mathrm{~h}$. Symbols:, $0 \%$ (control); $\bigcirc, 10 \% ; \nabla, 30 \% ; \nabla, 50 \%$.

에 젓산균 생균수는 대조군 $8.89 \log \mathrm{CFU} / \mathrm{g}$, 탈지분유 10,30 및 $50 \%$ 대체 요구르트는 각각 $8.65,8.44,8.02 \log \mathrm{CFU} / \mathrm{g}$ 으 로 탈지분유 대체 정도가 높아질수록 젖산균 생균수는 감소하 였다. 이러한 경향은 환원당의 함량의 변화(Fig. $2 \mathrm{~A}$ )와 일치하 는 것으로 발효과정에서 환원당의 감소가 가장 적은 탈지분유 를 $50 \%$ 대체한 실험구에서 젖산균 생균수가 가장 낮았다. 요 구르트의 젖산균 수는 $\mathrm{pH}$ 감소(Fig. 1A), 적정산도 증가(Fig. 1B), 환원당 감소(Fig. $2 \mathrm{~A}$ )와 동일하게 자색고구마 효소분해물 첨가 량에 비례하여 감소하였으며, 본 연구와 같이 자색고구마의 첨 가로 젖산균 수가 소폭 감소하는 결과는 우유에 부재료로 첨가 하는 탈지분유의 일부를 증자한 자색고구마 puree로 대체하여 요구르트를 제조하는 보고(Chun 등, 2000)와 매우 유사하였다. 탈지분유 함량이 증가할수록 젖산균의 생육도 증가하는 것을 고 려하면 이러한 경향은 탈지분유 사용량의 감소로 탈지분유에 함 유되어 있으며 젓산균의 증식에 필요한 비타민, 아미노산, purine 또는 pyrimidine 등의 복합영양소의 함량이 낮아지기 때문인 것 으로 사료된다. 또한 자색고구마 효소분해물에 포함되어 있는 단백질도 젖산균의 단백질 분해효소에 의하여 쉽게 분해되기 어 렵기 때문(Chun 등, 2000)인 것으로 생각된다. 전체적으로 복 합영양소가 젖산균의 생육 제한인자로 작용하는 것으로 판단되 었다. 그러나, 본 연구에서 젖산균 생균수가 가장 작은 $50 \%$ 대 체 구에서 젓산균수는 $8.0 \log \mathrm{CFU} / \mathrm{g}$ 이상으로 일반 발효유의 젖산균 생균수 성분규격인 $7.0 \log \mathrm{CFU} / \mathrm{g}$ 이상의 값을 나타내 므로 자색고구마 효소분해물로 탈지분유를 대체할 수 있을 것 으로 확인되었다.

관능특성. 자색고구마 효소분해물로 탈지분유의 대체량을 달리 하여 제조한 요구르트를 $40^{\circ} \mathrm{C}$ 에서 12 시간 발효시키고 설탕 $10 \%$ 를 가하고 $4^{\circ} \mathrm{C}$ 에서 24 시간 보관 다음 맛, 향, 색 및 종합 적인 기호도에 대한 관능평가 결과는 Table 1과 같다. 모든 항 목에서 대조구와 모든 실험구에서 통계적으로 유의적인 차이가 관찰되지는 않았다. 특이하게 색은 대조구와 실험군간의 유의차 가 없을 뿐만 아니라 점수도 3.3-3.6으로 거의 동일하여 자색 고구마의 색소에 의한 기호도 상승효과가 나타나지 않았으며, 자색고구마 분말을 첨가하면 적자색을 띠므로 색의 기호성이 증 
Table 1 Sensory evaluation results of yogurt prepared with different substitution ratios of skim milk with enzymatically hydrolyzed purple sweet potato powder after fermentation at $40^{\circ} \mathrm{C}$ for $12 \mathrm{~h}$

\begin{tabular}{|c|c|c|c|c|}
\hline Substitution level (\%) & Taste & Flavor & Color & Overall acceptability \\
\hline 0 & $3.40 \pm 0.70^{\mathrm{a}}$ & $3.30 \pm 0.67^{\mathrm{a}}$ & $3.60 \pm 0.84^{\mathrm{a}}$ & $3.80 \pm 1.03^{\mathrm{a}}$ \\
\hline 10 & $3.50 \pm 0.85^{\mathrm{a}}$ & $3.30 \pm 0.67^{\mathrm{a}}$ & $3.30 \pm 1.06^{\mathrm{a}}$ & $3.50 \pm 0.71^{\mathrm{a}}$ \\
\hline 30 & $4.20 \pm 0.63^{\mathrm{a}}$ & $3.60 \pm 0.70^{\mathrm{a}}$ & $3.60 \pm 0.84^{\mathrm{a}}$ & $4.20 \pm 0.63^{\mathrm{a}}$ \\
\hline 50 & $3.40 \pm 1.17^{\mathrm{a}}$ & $3.70 \pm 1.06^{\mathrm{a}}$ & $3.30 \pm 1.42^{\mathrm{a}}$ & $3.40 \pm 0.97^{\mathrm{a}}$ \\
\hline
\end{tabular}

${ }^{1)}$ Data are means $\pm \mathrm{SD}(n=10)$.

${ }^{2)}$ Different superscripts within column indicate significant difference $(p<0.05)$.

Table 2 Change in Hunter's color values of yogurt prepared with different substitution ratios of skim milk with enzymatically hydrolyzed purple sweet potato powder after fermentation at $40^{\circ} \mathrm{C}$ for $12 \mathrm{~h}$

\begin{tabular}{|c|c|c|c|c|c|}
\hline \multirow{2}{*}{ Hunter's values } & \multirow{2}{*}{ Incubation time (h) } & \multicolumn{4}{|c|}{ Substitution ratio $(\%)$} \\
\hline & & 0 & 10 & 30 & 50 \\
\hline $\mathrm{L}$ & 0 & 88.88 & 72.62 & 57.08 & 46.10 \\
\hline (Lightness) & 12 & 93.31 & 77.29 & 66.75 & 53.55 \\
\hline $\mathrm{a}$ & 0 & -2.29 & 11.91 & 14.25 & 15.94 \\
\hline (Redness) & 12 & -1.72 & 17.74 & 18.84 & 19.91 \\
\hline $\mathrm{b}$ & 0 & 9.05 & 2.48 & 19.16 & 16.33 \\
\hline (Yellowness) & 12 & 6.93 & 24.40 & 17.86 & 15.19 \\
\hline
\end{tabular}

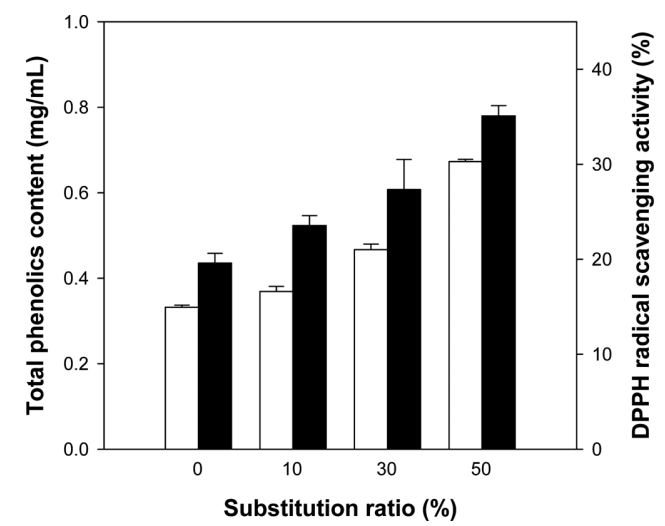

Fig. 3 Total phenolics content (open bar) and DPPH radical scavenging activity (closed bar) of yogurt prepared with different substitution ratios of skim milk with enzymatically hydrolyzed purple sweet potato powder after fermentation at $40^{\circ} \mathrm{C}$ for $12 \mathrm{~h}$.

가하였다는 결과(Jung과 Ju, 1997)와 차이를 보였다. 비록 통계 적으로 유의하지는 못하지만 맛과 전체적인 기호도는 탈지분유 의 $30 \%$ 를 대체하여 제조한 요구르트가 4.2점으로 가장 우수하 였으므로 탈지분유의 사용량의 $30 \%$ 를 자색고구마 효소분해물 로 사용하는 것이 적절한 것으로 조사되었다.

색도. 탈지분유의 사용량을 줄이고 자색고구마 효소분해물의 사 용량을 증가시키고 12 시간 발효하여 제조한 요구르트의 색도를 비교한 결과는 Table 2와 같다. 젖산균 배양 전 원료의 색도는 대조구에 비하여 자색고구마 효소분해물의 사용량이 증가하면 lightness의 L값은 감소하였으며, redness의 a값과 yellowness의 $\mathrm{b}$ 값은 증가하였다. 이러한 경향은 12 시간 발효시킨 요구르트의 색도에서도 동일하였다. $\mathrm{L}$ 값의 감소와 $\mathrm{a}$ 값의 증가는 자색고구 마에 함유된 anthocyanin 색소에 기인하는 것으로 증자한 자색 고구마 분말 혹은 puree를 첨가하여 제조한 요구르트(Jung과 Ju,
1997; Chun 등, 2000)에서와 동일한 경향이었다. 그러나 b값이 대조구에 비하여 증가한 결과는 기존의 보고(Jung과 Ju, 1997; Chun 등, 2000)와 상이한 것으로 이는 탈지분유에 자색고구마 효소분해물을 첨가한 것이 아니라 탈지분유를 자색고구마 분해 물로 대체한 발효기질을 사용한 차이에 기인하는 것으로 사료 된다. 또한 발효 후 요구르트의 $\mathrm{a}$ 값이 증가는 자색고구마 anthocyanin 색소가 낮은 산성조건 $(\mathrm{pH} 1-3)$ 에서 적자색을 나타 내는 특성 $(\mathrm{Kim}$ 등, 1996)이 있으므로 젖산균 발효과정에서 배 양액의 $\mathrm{pH}$ 하락(Fig. $1 \mathrm{~A}$ )에 의한 것으로, 자색고구마 이외에 anthocyanin 색소를 함유한 오디분말을 첨가한 요구르트에서도 동일한 결과가 보고되었다(Sung과 Choi, 2014).

항산화 활성. 자색고구마 효소분해물을 첨가하고 12 시간 배양 하여 제조한 요구르트의 총 폴리페놀 함량과 DPPH radical 소 거활성을 조사하였다(Fig. 3). 발효 12시간에 총 폴리페놀 함량 은 대조군 $0.332 \mathrm{mg} / \mathrm{mL}$, 탈지분유 10,30 및 $50 \%$ 대체 요구 르트는 각각 $0.369,0.467,0.673 \mathrm{mg} / \mathrm{mL}$ 로 탈지분유 대체 정도 가 높아질수록 증가하였으며, 이는 자색고구마 효소분해물 사용 량의 증가에 기인하는 것으로 판단된다. 젖산균 배양 전 원료 의 총 폴리페놀 함량(대조군; $0.583,10 \%$ 대체; $0.841,30 \%$ 대 체; $1.461,50 \%$ 대체; $1.850 \mathrm{mg} / \mathrm{mL}$ )과 비교하면 모든 실험군에 서 총 폴리페놀 함량은 감소하였다. 발효과정에서 총 폴리페놀 함량의 감소는 주로 열처리, $\mathrm{pH}$ 변화, 시간 경과 등에 따라 anthocyanin 색소 함량 감소에 기인하는 것으로 판단되며, 자색 고구마를 증자(steaming)하면 anthocyanin 함량이 약 $50 \%$ 감소 한다는 결과 $(\mathrm{Kim}$ 등, 2012)와 자색고구마 anthocyanin 색소는 $\mathrm{pH}$ 5.0-6.0보다 $\mathrm{pH}$ 2.0-4.0에서 안정하다는 결과(Fan 등, 2008; Jie 등, 2013)가 이러한 판단의 근거가 되었다. 그럼에도 불구하고 관능적으로 우수한 탈지분유 $30 \%$ 를 자색고구마 효소 분해물로 대체한 요구르트에는 대조구보다 총 폴리페놀 함량이 $40 \%$ 높은 것으로 나타났다. 본 연구와 동일하게 오디분말을 사 용한 요구르트의 제조에서도 발효시간 경과에 따라 총 폴리페 놀 함량이 감소하는 결과가 보고되어 있다(Sung과 Choi, 2014). 
자색고구마 효소분해물 요구르트의 DPPH radical 소거능은 대 조군 $19.60 \%$, 탈지분유 10,30 및 $50 \%$ 대체 요구르트는 각각 $23.56,27.34,35.10 \%$ 로 증가하였으며, 각 실험구의 총 폴리페 놀 함량변화와 동일한 경향이었다. 즉, 생리활성 물질인 총 폴 리페놀을 다량 함유한 자색고구마의 첨가로 인하여 요구르트의 항산화능이 증가되었다고 판단된다.

\section{초 록}

요구르트 제조시 사용하는 탈지분유의 일부를 자색고구마 효소 분해물로 대체(고형분 기준 $10,30,50 \%$ )하여 요구르트를 제조 한 후 탈지분유만을 사용한 대조구와 발효특성 $(\mathrm{pH}$, 적정산도, 환원당 함량, 젖산균의 생육), 생리활성(총 폴리페놀 함량, 항산 화 활성) 및 관능특성을 비교하였다. $\mathrm{pH}$ 는 모든 실험구에서 발 효 9시간까지 급격하게 감소하였으며, 그 이후 발효 15시간에 $\mathrm{pH} 3.9$ 부근까지 다소 완만하게 감소하였다. 적정산도는 $\mathrm{pH}$ 와 유사하게 모든 실험구에서 발효 9시간까지 급격하게 증가하였 으며 발효 15 시간 후 대조구는 $0.93 \%$, 자색고구마 분해물 첨가 요구르트는 $0.80-0.89 \%$ 로 자색고구마 분해물의 사용량이 증가 할수록 산의 생성은 감소하였다. 발효과정에서 자색고구마 분해 물의 사용량이 증가할수록 환원당 함량이 높게 유지되었다. 발 효 12시간에 대조군의 젖산균 생균수는 $8.89 \log \mathrm{CFU} / \mathrm{g}$, 자색 고구마 효소분해물 첨가 요구르트는 8.02-8.65 log CFU/g로 탈 지분유 대체 정도가 높아질수록 젖산균 생균수도 감소하였다. 관능검사 결과, 전체적인 기호도는 탈지분유의 $30 \%$ 를 대체하여 제조한 요구르트가 가장 우수하였다. 발효 12시간에 탈지분유 $30 \%$ 를 자색고구마 효소분해물로 대체한 요구르트의 총 폴리페 놀 함량은 대조구보다 $40 \%$ 높았으며, DPPH radical 소거활성 도 동일하게 증가하였다.

\section{Keywords 발효특성 - 요구르트 · 자색고구마 효소분해물 ·} 항산화 활성

감사의 글 본 연구는 2015 년도 청운대학교 학술연구조성비의 지원을 받아 수행하였습니다.

\section{References}

Almeida LB and Penteado MVC (1988) Carotenoids and pro-vitamin A value of white fleshed Brazilian sweet potatoes (Ipomoea batatas Lam.) $J$ Food Comp Anal 4, 341-52.

Blois MS (1958) Antioxidant determination by the use of a stable free radical. Nature 181, 1199-200.

Cho HK, Lee JY, Seo WT, Kim MK, and Cho KM (2012) Quality characteristics and antioxidant effects during Makgeolli fermentation by purple sweet potato-rice Nuruk. Korean J Food Sci Technol 44,728-35.

Cho JR, Kim JH, and In MJ (2007) Effect of garlic powder on preparation and quality characteristics of yogurt. J Korean Soc Appl Biol Chem 50, 48-52.

Choi YJ, Kim HA, Bang MA, Oh YB, Jeong BC, Moon YH et al. (2003) Protective effect of purple sweet potato (Ipomoea batatas) on hepatotoxicity rats induced carbon tetrachloride. Korean J Food Culture 18, 202-10.

Chun SH, Lee SU, Shin YS, Lee KS, and Ru IH (2000) Preparation of yogurt from milk added with purple sweet potato. Korean J Food \& Nutr 13, $71-7$.
Fan G, Han Y, Gu Z, and Gu F (2008) Composition and colour stability of anthocyanins extracted from fermented purple sweet potato culture. $L W T$ 41, 1412-6.

Folin O and Denis W (1912) On phosphotungstic-phosphomolybdic compounds as color reagents. J Biol Chem 12, 239-43.

Gilliland SE (1989) Acidophilus milk products, review of potential benefits to consumer. J Dairy Sci 72, 2483-9.

In MJ, Choi SY, Kim HR, Park DB, Oh MS, and Kim DC (2009) Acid production and phytate degradation using a Leuconoctoc mesenteroides KC51 strain in saccharified-rice suspension. J Appl Biol Chem 52, 33-7.

Jie L, Xiao-ding L, Yun Zhang, Zheng-dong Z, Zhi-ya Q, Meng L et al. (2013) Identification and thermal stability of purple-fleshed sweet potato anthocyanins in aqueous solutions with various $\mathrm{pH}$ and fruit juices. Food Chem 136, 1249-434.

Jung GT and Ju IO (1997) Studies on the preparation of yogurt from milk added purple sweet potato powder. Korean J Food \& Nutr 10, 458-61.

Kim DC, Kim C, and In MJ (2015) Antioxidant activities of extracts prepared from sweet potatoes with different flesh colors. J Appl Biol Chem 58, $21-4$.

Kim HS, Cha SM, Seong HY, Jung YJ, and In MJ (2014) Optimization of drying conditions for the production of purple sweet potato powder. $J$ Foodservice Ind Manage Res 10, 21-31.

Kim HW, Kim JB, Cho SM, Chung MN, Lee YM, Chu SM et al. (2012) Anthocyanin changes in the Korean purple-fleshed sweet potato, Shinzami, as affected by steaming and baking. Food Chem 130, 966-72.

Kim SJ, Rhim JW, Lee LS, and Lee JS (1996) Extraction and characterization of purple sweet potato pigment. Korean J Food Sci Technol 28, 345-51.

Ko SH and Seo EO (2010) Quality characteristics of muffins containing purple sweetpotato powder. J East Asian Soc Dietary Life 20, 272-8.

Lee EH, Nam ES, and Park SI (2002) Characteristics of curd yogurt from milk added with maesil (Prunus mume). Korean J Food Sci Technol 34, 419-24.

Lee IS and Paek KY (2003) Preparation and quality characteristics of yogurt added with cultured ginseng. Korean J Food Sci Technol 35, 235-41.

Lee JC, Lee KS, Lee JK, Han KH, and Oh MJ (1999) Preparation and characteristics of curd yogurt from milk added with purple sweet potato. Korean J Postharvest Sci Technol 6, 442-7.

Lee JS, Ahn YS, Kim HS, Chung MN, and Kim HS (2007) Biological activity of varieties, isolation and purification of antioxidants compounds in sweet potato. Korean J Breed Sci 39, 296-301.

Lee MJ, Kim YK, Kim KH, and Lee NY (2015a) Quality characteristics of whole barley flour added to yogurt during storage. Food Eng Prog 19, $8-13$.

Lee MJ, Lee YG, Cho JI, Na KC, Kim MS, and Moon JH (2014) Antioxidative activity of Cheonggukjang prepared with purple sweet potato. Korean J Food Sci Technol 46, 224-30.

Lee N, Kim CS, Yu GS, Park MC, Jung WO, Jung UK et al. (2015b) Effect of nitrite substitution of sausage with addition of purple sweet potato powder and purple sweet potato pigment. J Korean Soc Food Sci Nutr 44, 896-903.

Lee SH and Kang KM (2010) Effect of chitooligosaccharides on the fermentation characteristics and shelf life of yogurt. J Chitin Chitosan 15, 210-5.

Liu YN, Jeong DH, Jung JH, and Kim HS (2013) Quality characteristics and antioxidant activities of cookies added with purple sweet potato powder. Korean J Food Cookery Sci 29, 275-81.

Park JS, Bae JO, Choi GH, Chung BW, and Choi DS (2011a) Antimutagenicity of Korean sweet potato (Ipomoea batatas L.) cultivars. $J$ Korean Soc Food Sci Nutr 40, 37-46.

Park SJ, Kim JM, Kim JE, Jeong SH, Park KH, and Shin M (2011b) Characteristics of sweet potato powders from eight Korean varieties. Korean J Food Cookery Sci 27, 19-29.

Ravindran V, Ravindran G, Sirakanesan R, and Rajaguru SB (1995) Biochemical and nutritional assessment of tubers from 16 cultivars of sweet potato. J Agric Food Chem 43, 2646-51.

Seo WT, Kim HG, Lee JS, and Cho KM (2011) Making of Dongchimi Naengmyeun broth which has enhanced antioxidant activity using purple sweet potato. Korean J Microbiol 47, 143-50. 
Sung JM and Choi HY (2014) Effect of mulberry powder on antioxidant activities and quality characteristics of yogurt. J Korean Soc Food Sci Nutr 43, 690-7.

Sung YM, Cho JR, Oh NS, Kim DC, and In MJ (2005) Preparation and quality characteristics of curd yogurt added with chlorella. $J$ Korean Soc Appl Biol Chem 48, 60-4.

Walstra P and Jenness R (1984) In Dairy Chemistry and Physics, John Wiley and Sons, USA. 